Article

\title{
Social Media University Branding
}

\author{
Petra Maresova ${ }^{1}$ (D), Jan Hruska ${ }^{1}$ (D) and Kamil Kuca ${ }^{2, *(\mathbb{D})}$ \\ 1 Department of Economics, University of Hradec Kralove, 50003 Hradec Kralove, Czech Republic; \\ petra.maresova@uhk.cz (P.M.); jan.hruska.3@uhk.cz (J.H.) \\ 2 Center for Basic and Applied Research, University of Hradec Kralove, 50003 Hradec Kralove, \\ Czech Republic \\ * Correspondence: kamil.kuca@uhk.cz
}

Received: 28 January 2020; Accepted: 10 March 2020; Published: 16 March 2020

\begin{abstract}
Globalization has increased the demands placed on higher education and increased competition among universities. In response, institutions of higher education have started to consider their online presence as a potential competitive advantage. The aim of this article is to analyze and compare Facebook activity and content created by the world's top ten universities. The professional social media analytics tool Socialbakers is used to monitor activity and collect data for analysis. The world's top ten universities are determined based on the Quacquarelli Symonds (QS) University Rankings. The study results are divided into four categories: an analysis of the number of fans, of content, of style, and of post promotion. All of the studied universities upload a post at least once per day. Based on the study results, selected posts could be examples of best practice and serve to inspire other educational institutions to improve their brand image and communication on social networks. Social media provide a large amount of detailed data concerning the behavior of students and other stakeholders and on the effectiveness of promotional campaigns. To use social media effectively, it is necessary to collect the available data and evaluate them to gain insight on which to base an appropriate social media strategy
\end{abstract}

Keywords: universities; social media; Facebook; social marketing

\section{Introduction}

At the turn of the 21st century, society underwent a dramatic change that affected higher education. The continuing digitalization of most aspects of our lives and the globalization of the job market increased the demands placed on higher education and competition among universities. In response, institutions of higher education started to consider their online presence as a potential competitive advantage. Universities and colleges are aware of the marketing and branding potential of the internet in general and social media in particular [1]. However, research studies indicate that their efforts are often ineffective because these institutions lack a solid social media strategy designed with a target audience in mind [2].

In 2019, the number of social network users reached 3.484 billion. The total number of Facebook users in 2019 was 2.234 billion [3,4]. Within the target group of students and prospective students, social media use is widespread - in the 18 to 29 years age group, $90 \%$ use social media regularly [3,4]. Young adults use various social media services, such as Twitter, Instagram, and Snapchat [5], or Facebook. In Japan, the social network Line is the most used, while in Russia, VKontakte is by far the most popular among social media [6]. In China, Weibo is the most widely used network because the Chinese government does not accept global social networks, such as Facebook or Twitter, due to internet security limitations. According to statistics, university students report using social media daily. Current students and graduates state that they use Facebook and other social media to connect 
and reconnect with their university peers [7]. Social media are particularly important for freshmen and prospective students, who access them to find practical information and build relationships in their new environment [8]. Social media offer both opportunities and challenges that require profound knowledge to develop and implement strategies successfully. Accordingly, scholars have made persistent attempts to define and classify social media platforms, and to understand their role in marketing [9].

The cited data support the assumption that social media have become an important channel for universities to raise awareness regarding their brand image and nurture brand loyalty, i.e., a sense of community spirit surrounding a particular university. Despite these facts, research shows that many educational institutions do not utilize social media to their advantage and present a confusing brand image, which ultimately results in negative rather than positive outcomes [5]. Thus, this paper selects the world's 10 most influential universities according to the Quacquarelli Symonds (QS) rankings, as it is one of the top international rankings measuring the popularity and performance of universities all over the world [10] and analyzes their social media activity while considering the following research questions: What is the nature of the social media activity of these universities? What type of content do they produce and how often do they post? Do they actively engage and interact with their users? Since university rankings remain relatively stable and do not tend to change drastically from year to year [11], lower-ranking universities find it difficult to compete. Such institutions may find it to their advantage to influence their students and promote their brand image by alternative means, such as on social media.

\section{Theory and Literature Review}

For the purpose of this paper, let us first define the key terms to be used in the following discussion. The paper focuses on higher education institutions (HEI), more specifically, universities and their behavior on social media. In the European context, the term HEI is understood as describing institutions offering higher education, that is, postsecondary or tertiary [12-14]. The term covers both traditional, academically focused universities and vocational, profession-focused universities. Public universities have a unique standing in that they are non-profit organizations which pursue a complex and sometimes contradictory mission [15]. This is because they seek to cater to the requirements of various stakeholders, which may bring about internal contradictions and diffuse any single, unified mission. In the light of these facts, it is obvious that unlike businesses, public universities cannot measure their performance with respect to their mission [16]. Factors influencing the performance of HEIs are often global and include, for example, policies of international publishing houses and the availability of R\&D funding worldwide. These and other global influences are not always positive, which challenges the popular belief that globalization, including the increasing spread of information by means of internet publishing, is a phenomenon that unequivocally democratizes knowledge. While the contribution of the internet and other global tools to disseminating knowledge is indeed invaluable, evidence suggests that the impact of globalization may not always be beneficial. Nevertheless, what globalization does enable is offering researchers and students the opportunity to work and study anywhere [17].

Given that universities find themselves operating within dynamic and challenging environments, marketing strategy becomes a priority in assuring strong student and faculty recruitment and retention [18].

\subsection{Social Media Technologies}

Social networks have many advantages over traditional websites. One of the main advantages is the possibility of reaching a large audience quickly. This may be amplified at the beginning by paid contributions. Other benefits include direct connectivity with social networking users and thus getting feedback $[19,20]$. In this way, services offered to the customer can be improved, and the companies or organizations can get to know their customer or candidate better. Each post also shows how 
interesting it is, which is reflected in how many people viewed, commented, and shared it. In this respect, traditional websites are better for a more in-depth presentation of the company and product. The disadvantages of social networks include the possibility of receiving negative feedback, which can also spread rapidly and be destructive $[9,19]$.

The use of social media is connected with the latest advances in technology. For example, virtual reality (VR) enables an immersive infotainment experience, recently even having started to offer the option to connect to motion sensors and interact with objects presented on the screen [21]. This is an entirely new way of presenting content, and high-end VR developers are working on exploiting this option in full-Facebook and HTC have both launched VR headset development initiatives to this effect, Oculus Rift and HTC Vive, respectively. An increasing number of HEIs rely on what is known as chatbots [22]. Chatbots, short for chatterbots, are computer programs that serve as virtual assistants, imitating human conversation. They are able to interact through text messages or voice and can be embedded in various messaging applications to answer the most common questions asked by students. Initially, chatbots were only used at universities for simple tasks, helping students in specific areas, but more and more universities are looking to utilize chatbots more broadly for various purposes [23,24].

\subsection{Brand Management in Higher Education}

Research in the field of university social media branding, e.g., [25,26], or [27], most often focuses on the perspective of students and investigates to what extent the social media image of a particular, in the case of this paper-university, influences the attractiveness of this institution for students. Universities face increasing competition in attracting and retaining the best students, and social media are seen as a more viable method of communication between the institution and its constituents, including the current students, prospective students [28,29], parents, alumni, and community members. Peruta (2017) [29] explained that brand management in higher education is similar to the case of non-profit brands, but it may not necessarily be suited to the specific needs of the university sector, due to greater competition in the market [30].

According to [31], it no longer suffices for universities to spark interest in knowledge. They must learn competitive business strategies to attract students as well as funding. To these ends, social media represent a tool of major importance.

In academia, social media represent a completely new means of communication and collaboration, one which is gradually changing the behavior of researchers worldwide with respect to how they publish their research and interact with fellow researchers and the non-specialist audience [32]. The authors of [33] emphasize the high competitiveness of the higher education market and contend that a favorable media image and solid reputation are crucial tools for higher education institutions. The author of [34] presents empirical evidence indicating that a strong brand gives universities advantages over their competitors. A strong brand is built on the basis of the experience of students in the course of their studies. Student loyalty increases when students feel that their university communicates with them well and meets their various needs, including through the university's communication on social media. Social media strategy is increasingly becoming an integral part of brand marketing, which also applies to education market brands [35]. The authors of [36] suggest that social media were originally used by brands simply as an afterthought and that social media brand content was neither indispensable nor influential to start with. However, as [37] observe, social media today are so powerful that they can easily make or break a brand's reputation and directly lead to a success or failure of the brand. While brand managers, whether at educational institutions or other enterprises, are generally aware of the opportunities presented by social media, there is a surprising lack of coherent knowledge regarding how to develop an effective digital marketing strategy to build a consistent brand image [1]. Social media campaigns do not need to be expensive. Their outcome relies on the quality of the campaign rather than the size of the campaign budget. The power of social media lies in the fact that they can deliver engaging multimedia content, including not only text but also images, videos, and even gifs or memes, where appropriate $[38,39]$. The message communicated via social media 
must be eye-catching, both informative and entertaining to draw the interest of the audience and build brand loyalty. Reuben (2008) [20] describes how Ohio State University uses social networking sites, such as Facebook, YouTube, Flicker, and Delicious, as part of its social media strategy with the goal of developing interaction with its target audience [32]. According to the National Research Center for College and University Admissions (USA) (2016), more than $60 \%$ of high-school seniors in 2007 preferred student and faculty blogs to other information sources, and $80 \%$ of students in high school stated they would read or respond to a message from a college representative. In addition, $57 \%$ of teenagers online reported using the internet to find information on a college or university [40]. The rapid growth and variety of social media networks suggests that prospective university and college students will be open and positive to institutions adopting these technologies as methods of recruitment [41].

The use of a mixture of new marketing techniques is also recommended: virtual environments, social utility groups, novelty messaging, gaming environments, interactive promotions, merchandising, and cross-promotions. Kurre et al. (2012) [42,43] discuss how social media influence the self-presentation of higher education institutions in the digital world, where they are "creating communities of learners where education and contemporary culture intersect". Kurre et al. (2012) [44] note the challenge faced by competing colleges and universities, all of which ultimately offer the same service with only minor differences. Through social media, individual institutions of higher education may distinguish themselves from their competitors by developing and pursuing an effective media campaign to engage their audience and inspire brand loyalty.

\section{Methods}

This section will describe the research procedure, the sample analyzed, and the variables used. The choice of universities and the method used will be described.

\subsection{Research Design}

The aim of this article is to analyze and compare Facebook activity and content created by the world's top ten universities. The professional social media analytics tool Socialbakers was used to monitor the social media activity of the selected universities and collect data for analysis. The analyzed data include the content of selected posts and user engagement with them.

\subsection{Sample}

The world's top ten universities were determined based on the QS University Rankings, which rates each university in six different categories: academic reputation, employer reputation, faculty- student ratio, international faculty, international students, and citations per faculty member [40]. The rankings reflect which universities were considered best in 2017.

The rankings include global overall and subject ratings, resulting in an overview of the world's top universities in 48 subjects and 5 composite faculty areas. The QS World University Rankings are published annually and are the most prestigious and most widely referred to rankings in this area [10]. Apart from locally relevant university rankings (e.g., Emerging Europe, Latin America, Central Asia, etc.), other global rankings with a long tradition and solid reputation include those published by the ShanghaiRanking Consultancy (Academic Ranking of World Universities; ARWU), Times Higher Education (THE), and Quacquarelli Symonds (QS). The shared shortcoming of most of these rankings is that they are biased towards research performance, which they value higher than the teaching delivered by universities. The ARWU, to name but one, is known for ignoring "the quality of teaching or the quality of humanities" altogether and relying solely on research indicators [17,43]. For this reason, our paper makes use of the QS rankings because they employ the most complex set of criteria for evaluating the performance of a particular university [31].

Based on the QS University Rankings, Massachusetts Institute of Technology (MIT) is considered to be the world's top university. The second is Harvard University (HU). In third place, there is a 
tie between University of Cambridge (CU) and Stanford University (SU). In fifth place is California Institute of Technology (Caltech). Places 6 to 10 are occupied by University of Oxford, University College London (UCL), ETH Zurich-Swiss Federal Institute of Technology, Imperial College London, and the University of Chicago, respectively.

\subsection{Measures and Data Collection}

Using the Socialbakers analytics tool, the collected data were first exported to an XLS file and subsequently processed, analyzed, and organized in tables to present the results. The main variables that were examined when researching the social media activity of the selected universities included the total number of fans, their countries of origin, any significant changes in the given time range, the sources of published posts, post content, audience engagement, and the proportion of promoted posts. The results were divided into four categories: analyses of the number of fans, of content, of style, and of post promotion. The categories were selected prior to starting research, based on surveying literature published on this subject to determine which issues are relevant to an organization's presence on social media (such as here $[44,45]$ ) and based on data available in the Socialbakers professional tool.

\section{Results and Findings}

The world's top ten universities were examined with respect to what social networks they use. This information was obtained directly from the official websites of the universities. All the selected universities have their accounts on Facebook, Instagram, Twitter, and YouTube.

All the selected universities are active on Instagram, Twitter, and YouTube. In the case of Instagram, the university is usually introduced in one sentence in the account description, followed by a link to their website. The only exception is Imperial College London, which does not have a link to its website and instead encourages users to tag their photos with the university hashtag. In the case of Instagram, universities usually add one or two posts per day. These posts most often depict university premises or point to university achievements or famous personality stories. Twitter activity is comparable to Instagram social network activity, but enhanced with article sharing, which most often includes a university achievement or an ongoing event. University activity on YouTube is smaller than on Instagram and Twitter, but each of these universities adds a few videos a month. Shorter videos are usually added - no longer than five minutes-but most of the universities also upload longer videos with presentations and lectures. Furthermore, the selected universities were examined with respect to their fan base on Facebook, the means of promotion used by the universities, and the content of the successful posts. All the selected universities are very active on Facebook, where they also have the largest following, as shown in Table 1. They add several posts per day. All of them have also completed contact details and a university description. This is why Facebook was selected for an in-depth analysis. 
Table 1. Used social media by universities.

\begin{tabular}{|c|c|c|c|c|c|}
\hline \multirow[b]{2}{*}{ University } & \multirow[b]{2}{*}{$\begin{array}{l}\text { Facebook } \\
\text { Fans }\end{array}$} & \multicolumn{4}{|c|}{$\begin{array}{c}\text { Numbers of Fans on Instagram, Twitter, YouTube and Other Social } \\
\text { Media Used by Universities. }\end{array}$} \\
\hline & & $\begin{array}{l}\text { Instagram } \\
\text { Fans }\end{array}$ & $\begin{array}{l}\text { Twitter } \\
\text { Fans }\end{array}$ & $\begin{array}{l}\text { YouTube } \\
\text { Fans }\end{array}$ & Other \\
\hline Harvard University & $5,241,925$ & $1,1516,932$ & $1,030,890$ & $1,110,000$ & SoundCloud, LinkedIn, iTunes \\
\hline University of Oxford & $3,536,510$ & 666,236 & 569,158 & 185,000 & $\begin{array}{l}\text { iTunes, LinkedIn, Weibo, } \\
\text { Medium, The Conversation }\end{array}$ \\
\hline University of Cambridge & $2,087,263$ & 731,967 & 506,048 & 193,000 & LinkedIn, Weibo \\
\hline Stanford University & $1,253,454$ & 712,116 & 727,161 & $1,060,000$ & iTunes \\
\hline MIT & $1,097,487$ & 248,248 & $1,059,967$ & 567,000 & \\
\hline Caltech & 375,012 & 44,016 & 80,189 & 114,000 & Coursera \\
\hline University of Chicago & 241,657 & 99,092 & 57,611 & 51,000 & \\
\hline UCL & 181,903 & 91,015 & 71,471 & 22,000 & SoundCloud, Flickr, Medium \\
\hline Imperial College London & 162,333 & 65,939 & 108,049 & 101,000 & LinkedIn, Weibo \\
\hline ETH Zurich & 56,909 & 42,580 & 39,848 & 17,200 & LinkedIn \\
\hline
\end{tabular}

\subsection{Analysis of Facebook Fan and Reaction Numbers}

Fans are users of Facebook that "like" the Facebook page of a company or organization. By liking a page, people demonstrate that a page caught their interest and that they want to receive updates regarding the latest news, special offers, and content that the page publishes. Every post has a metric number of interactions per 1000 fans, which identifies how engaging a post is. This number represents the sum of interactions (i.e., reactions, comments, and shares) divided by the number of fans a page has on the day the post was published and multiplied by 1000 .

The world's top universities are internationally known, and all publish Facebook content in English, so their pages are easily accessible to new fans. HU has the largest fan base on Facebook, whereas Caltech has the smallest Facebook page based on the number of fans. When we examine the distribution of fans according to country of origin, we find several interesting patterns. Five of the ten top universities are American: Caltech, Harvard University, MIT, Stanford University, and the University of Chicago. However, in the case of Caltech and MIT, two technological universities, most Facebook fans are from India, followed by the USA. In the case of Caltech, the third-ranked fan country of origin is Bangladesh, whereas for MIT, Brazil ranks third. Harvard University and Stanford University both have fan majorities from the country in which they are located-USA. They also enjoy quite numerous fan bases in India, Brazil, and Mexico. The University of Cambridge is located in the United Kingdom. However, local fans represent only $4.61 \%$ of the university's Facebook fans. The leading home country of this university's fans is India, followed by Pakistan, Egypt, Bangladesh, the USA, and then the United Kingdom.

\subsection{Content Analysis}

When publishing content on Facebook, a page administrator can choose from many different post types. For example, pages can publish links, photos, videos, albums, and text statuses. Content published by the ten studied universities was analyzed based on post type, and the results are shown in Table 2. Within only one decade, the role of technology in public relations has grown tremendously, and content published online has come to play a key role [46].

The most popular type of post is a link. Approximately $60 \%$ of all the content created by the ten analyzed universities is of this type. The proportion of photo and video posts together is approximately $20 \%$ for each of the selected universities. The leading university in number of posts in the analyzed 365-day range is $\mathrm{HU}$, with 581 posts, while the least active university is SU, with 397 posts, although all the universities post with a similar frequency. The fan increase column in the table indicates how many users were added as fans of a page between July 2017 and July 2018. 
Table 2. Total number of Facebook fans and reactions over 365 days (July 2017 to July 2018).

\begin{tabular}{ccccccc}
\hline University & Fans & Reactions & Comments & Shares & MEPT & SI1000 \\
\hline Harvard University & $5,241,925$ & 991,000 & 46,100 & 197,000 & Video & 240.0 \\
University of Oxford & $3,536,510$ & 300,000 & 19,400 & 33,600 & Photo & 103.4 \\
University of Cambridge & $2,087,263$ & 483,000 & 20,400 & 399,000 & Video & 467.9 \\
Stanford University & $1,253,454$ & 195,000 & 8300 & 24,400 & Link & 183.3 \\
MIT & $1,097,487$ & 364,000 & 17,000 & 61,000 & Video & 420.8 \\
Caltech & 375,012 & 71,500 & 2900 & 7600 & Photo & 223.8 \\
University of Chicago & 241,657 & 140,000 & 12,000 & 21,200 & Video & 746.8 \\
UCL & 181,903 & 64,800 & 4400 & 5300 & Video & 442.8 \\
Imperial College London & 162,333 & 96,100 & 4600 & 9400 & Photo & 712.1 \\
ETH Zurich & 56,909 & 39,500 & 1400 & 8000 & Video & 9624.0 \\
\hline
\end{tabular}

MEPT = most engaging post type; SI1000 = sum of interactions per 1000 fans per period.

\subsection{Post Style and Promotion}

Because Facebook constantly decreases the organic reach of page posts [47], it became necessary for marketers to promote selected posts. Otherwise, these posts would be unable to reach as many readers as they could a few years ago. If one desires to promote a post on Facebook, one can target the page's advertisements according to where selected users live, their age, their interests, and other variables. Large Facebook pages (i.e., 500,000+ fans) promote more than $25 \%$ of their published posts. Socialbakers includes a special tool that can detect promoted posts. It distinguishes three basic types of post: promoted (paid), organic, and undetected. For the ten selected universities, the percentage share of each of these three post types is listed in Table 3 and for special tool that can detect promoted posts see Table 4 .

Table 3. Facebook content published by universities by post type (July 2017 to July 2018).

\begin{tabular}{ccccccc}
\hline University & Posts & Link & Video & Photo & Status & Fan Increase \\
\hline Harvard University & 575 & 374 & 121 & 84 & 0 & 165,000 \\
University of Oxford & 474 & 9 & 181 & 283 & 2 & 208,000 \\
University of Cambridge & 452 & 196 & 169 & 75 & 5 & 230,000 \\
Stanford University & 544 & 330 & 147 & 72 & 9 & 41,300 \\
MIT & 513 & 290 & 125 & 101 & 1 & 100,000 \\
Caltech & 521 & 289 & 87 & 138 & 10 & 23,600 \\
University of Chicago & 343 & 112 & 93 & 137 & 2 & 11,400 \\
UCL & 440 & 137 & 38 & 261 & 6 & 16,400 \\
Imperial College London & 993 & 343 & 201 & 430 & 2 & 12,400 \\
ETH Zurich & 417 & 246 & 96 & 76 & 0 & 10,300 \\
\hline
\end{tabular}

Table 4. Promoted post detection (July 2017 to July 2018).

\begin{tabular}{ccccc}
\hline Facebook Page & Promoted & Organic & Undetected & Total \\
\hline Harvard University & 8 & 453 & 118 & 579 \\
University of Oxford & 24 & 369 & 82 & 475 \\
University of Cambridge & 22 & 394 & 29 & 445 \\
Stanford University & 14 & 531 & 13 & 558 \\
MIT & 7 & 449 & 61 & 517 \\
Caltech & 11 & 456 & 50 & 517 \\
University of Chicago & 9 & 261 & 74 & 344 \\
UCL & 13 & 407 & 22 & 442 \\
Imperial College London & 27 & 893 & 56 & 976 \\
ETH Zurich & 10 & 357 & 51 & 418 \\
\hline
\end{tabular}

This market and social media itself remain novel promotional channels for universities. The table also shows that Socialbakers analytics are not $100 \%$ accurate. That is, a considerable number of posts 
marked as undetected could be either promoted or organic. Social media are perceived by consumers as a more trustworthy source of information regarding products and services than corporate-sponsored communications transmitted via the traditional channels of the promotion mix [48]. The consumers' ability to communicate with one another limits the amount of control companies have over the content and dissemination of information [49].

All of the selected universities upload a post every day, and it is not exceptional that they post even more than once daily. Therefore, all of the selected universities believe that consistency is a key to success on social media. Universities are also using student/user-generated content and share, for example, student videos/photos or information regarding student accomplishments. In this manner, the institutions try to remain interesting, also posting on all types of interesting research from around the world. One gains the impression that they are consciously seeking to live up to their reputations as the world's most famous universities. How to determine in advance which posts will "go viral" is a question not yet fully understood. However, the top universities have achieved impressive results with certain posts (on Facebook). Top posts of selected universities are shown in the table below (see Table 5).

Table 5. Top Facebook posts of selected universities between July 2017 and July 2018.

\begin{tabular}{|c|c|c|c|c|}
\hline University & Post text & Type & Shares & $\begin{array}{l}\text { Interactions } \\
\text { per } 1000 \text { Fans }\end{array}$ \\
\hline $\begin{array}{l}\text { Harvard } \\
\text { University }\end{array}$ & $\begin{array}{c}\text { Acclaimed composer John Williams was treated to a special } \\
\text { a cappella tribute by Harvard students at Commencement. } \\
\text { Recognize these songs? }\end{array}$ & Video & 81,605 & 30.5 \\
\hline $\begin{array}{l}\text { Harvard } \\
\text { University }\end{array}$ & $\begin{array}{l}\text { Mark Zuckerberg in his old Harvard dorm room at the desk } \\
\text { where he launched the first version of Facebook in } 2004 . \\
\text { Take a look around! Mark is back on campus to speak at our } \\
2017 \text { Commencement on May 25th! Be sure to tune in live. }\end{array}$ & Photo & 4396 & 11.96 \\
\hline $\begin{array}{l}\text { Harvard } \\
\text { University }\end{array}$ & Insu Kim wore his thesis to Commencement & Photo & 1789 & 4.84 \\
\hline $\begin{array}{l}\text { University of } \\
\text { Oxford }\end{array}$ & $\begin{array}{l}\text { We're very proud to call Stephen Hawking an alumnus of } \\
\text { Oxford, and enormously saddened by his passing. Our } \\
\text { thoughts are with his family. He reminded us all to 'be } \\
\text { curious', for there is 'always something you can do and } \\
\text { succeed at'. }\end{array}$ & Photo & 1298 & 2.6 \\
\hline $\begin{array}{l}\text { University of } \\
\text { Oxford }\end{array}$ & $\begin{array}{l}15 \text { years ago, my parents received a letter from the primary } \\
\text { school council I was attending, recommending a shift to a } \\
\text { high-school for children with learning disabilities. The truth } \\
\text { is that my only 'disability' was that I was first-generation } \\
\text { 'migrant' child with some language difficulties and little to } \\
\text { no learning support at home. Nonetheless, I had more than } \\
\text { enough love and care! My parents fought against that } \\
\text { recommendation, and last weekend I received my MSc in } \\
\text { Evidence-Based Social Policy from the University of } \\
\text { Oxford-with distinction. Do not let anyone tell you who } \\
\text { you are and what you can achieve! }\end{array}$ & Link & 704 & 2.29 \\
\hline $\begin{array}{l}\text { University of } \\
\text { Cambridge }\end{array}$ & Professor Stephen Hawking 1942-2018. A video tribute. & Video & 344,741 & 290.1 \\
\hline $\begin{array}{l}\text { University of } \\
\text { Cambridge }\end{array}$ & $\begin{array}{c}\text { "Look up at the stars and not down at your feet" - Professor } \\
\text { Stephen Hawking 1942-2018 }\end{array}$ & Photo & 15,342 & 20.42 \\
\hline $\begin{array}{l}\text { University of } \\
\text { Cambridge }\end{array}$ & $\begin{array}{l}\text { "University of Cambridge updated their cover } \\
\text { photo."-Uploaded new profile photo of Stephen Hawking }\end{array}$ & Photo & 808 & 4.37 \\
\hline $\begin{array}{l}\text { Stanford } \\
\text { University }\end{array}$ & $\begin{array}{l}\text { We're sad to share that Maryam Mirzakhani, the first } \\
\text { woman to win a Fields Medal, has died. She was a pure } \\
\text { mathematician and was drawn to solving some of the most } \\
\text { difficult problems in math. She was particularly excellent at } \\
\text { developing ways to calculate the surfaces of curved objects } \\
\text { with increasing precision, which has many downstream } \\
\text { implications in everyday life. }\end{array}$ & Link & 3133 & 16.36 \\
\hline
\end{tabular}


Table 5. Cont.

\begin{tabular}{|c|c|c|c|c|}
\hline University & Post text & Type & Shares & $\begin{array}{l}\text { Interactions } \\
\text { per } 1000 \text { Fans }\end{array}$ \\
\hline $\begin{array}{l}\text { Stanford } \\
\text { University }\end{array}$ & $\begin{array}{l}\text { Congratulations to the 2,050 students-from } 50 \text { states and } 82 \\
\text { countries-offered undergraduate admission to the Class of } 2021\end{array}$ & Photo & 306 & 4.17 \\
\hline $\begin{array}{l}\text { Stanford } \\
\text { University }\end{array}$ & \#WelcomeToStanford, Alex Little! & Video & 129 & 3.41 \\
\hline MIT & $\begin{array}{l}\text { A robot developed by MIT students Ben Katz and Jared Di Carlo } \\
\text { can solve a Rubik's Cube in a record-breaking } 0.38 \text { seconds. }\end{array}$ & Video & 6015 & 18.38 \\
\hline MIT & $\begin{array}{l}\text { For the 6th straight year, MIT has been named the world's No. } 1 \\
\text { university by QS Top Universities. }\end{array}$ & Link & 871 & 7.19 \\
\hline MIT & $\begin{array}{l}\text { Amazing! Scientists have made the first detection of gravitational } \\
\text { waves produced by colliding neutron stars. Witnessed by more } \\
\text { than } 70 \text { observatories worldwide, this marks the first cosmic event } \\
\text { observed in both gravitational waves and light. }\end{array}$ & Video & 2324 & 6.13 \\
\hline Caltech & $\begin{array}{c}\text { Caltech joins the world in mourning the passing of } \\
\text { Stephen Hawking. }\end{array}$ & Link & 271 & 4.44 \\
\hline Caltech & $\begin{array}{l}\text { Happy Birthday to Caltech's Richard Feynman, who would have } \\
\text { been } 99 \text { today. And check out Feynman's lectures online }\end{array}$ & Link & 313 & 4.33 \\
\hline Caltech & $\begin{array}{l}\text { At home earlier this morning with our newest Nobel Laureates, } \\
\text { Barry Barish (with wife Samoan) and Kip Thorne (BS '62), after } \\
\text { they received the exciting news from Stockholm. \#NobelPrize }\end{array}$ & Photo & 66 & 3.79 \\
\hline $\begin{array}{l}\text { University of } \\
\text { Chicago }\end{array}$ & $\begin{array}{l}\text { Prime Minister Justin Trudeau of Canada at the University of } \\
\text { Chicago Institute of Politics: We're live from Mandel Hall for our } \\
\text { fifth anniversary celebration event with Prime Minister Justin } \\
\text { Trudeau of Canada. The Prime Minister will give remarks } \\
\text { followed by a moderated Q\&A with David Axelrod. This event } \\
\text { will end at 5:30pm CT. }\end{array}$ & Video & 1443 & 52.61 \\
\hline $\begin{array}{l}\text { University of } \\
\text { Chicago }\end{array}$ & $\begin{array}{l}\text { Seventy-five years ago, the world's brightest minds gathered at } \\
\text { the University of Chicago to embark upon a top-secret } \\
\text { government project. In an anxious war-time atmosphere, they } \\
\text { worked beneath the stands of Stagg Field in a race to conduct the } \\
\text { first nuclear chain reaction. 'From the middle of October until } \\
\text { Dec. 2, we were on a regime of about } 90 \text { hours of work a week. } \\
\text { All we did was to work and sleep, and sometimes we didn't even } \\
\text { get to eat meals.'-Project scientist Albert Wattenberg, PhD'47 }\end{array}$ & Link & 2218 & 47.05 \\
\hline UCL & $\begin{array}{l}\text { UCL continues to place in the top } 20 \text { universities in the world, } \\
\text { according to the Times Higher Education's } 2018 \text { rankings. }\end{array}$ & Link & 630 & 29.16 \\
\hline UCL & $\begin{array}{l}\text { Therapy dogs were on campus today for World Mental Health } \\
\text { Day, thanks to UCLcares. }\end{array}$ & Photo & 138 & 16.38 \\
\hline $\begin{array}{l}\text { Imperial } \\
\text { College } \\
\text { London }\end{array}$ & $\begin{array}{l}\text { People who drink around three cups of coffee a day may live } \\
\text { longer than non-coffee drinkers, a landmark study has found. }\end{array}$ & Link & 1111 & 19.03 \\
\hline $\begin{array}{l}\text { Imperial } \\
\text { College } \\
\text { London }\end{array}$ & $\begin{array}{l}\text { "Imperial has changed the way we think about the universe": } \\
\text { Professor Stephen Hawking is awarded an honorary doctorate by } \\
\text { the College }\end{array}$ & Link & 163 & 15.56 \\
\hline ETH Zurich & $\begin{array}{l}\text { At the thinnest point, the roof is only } 3 \text { centimeters thick! The } \\
\text { construction would have been inconceivable without } \\
\text { state-of-the-art computation and fabrication techniques. }\end{array}$ & Video & 3338 & 103.7 \\
\hline ETH Zurich & ETH Zurich from above. & Photo & 62 & 33.68 \\
\hline
\end{tabular}

Universities tend to use social media primarily to share the latest news, and the best-performing posts are often those that report on a particular success of the university, such as the development of a robot prototype or the success story of an individual student. Another common feature of posts shared by universities are announcements regarding the deaths of world-renowned researchers, in which the universities pay homage and target the emotions of readers. Generally, all the studied universities focus on fresh, interesting news and avoid sharing study resources, promotional videos, or 
posts promoting the quality of the university. Instead, they seek to entertain, inform, and even shock their fans.

Social networks are complex systems, and it is challenging to understand all their connections and variables. However, based on the research described in this paper, certain social media activities stand out and are practiced by all top ten selected universities. These similarities include frequent activity on the Facebook, Instagram, Twitter, and YouTube social networks. It is common to add posts several times a day. The only exception is YouTube, where the universities add several videos a month. The Socialbakers analytical software has found that universities rarely use promoted content and usually rely on organic reach. Similarly, it has been found that universities most often share posts where a video or photo is added, avoiding posts with text only. Posts most often contain the achievements of the universities and often mention celebrities, new inventions, and studies.

\subsection{Summary}

The social media channels of all the studied universities are very consistent with respect to their posting behavior, posting one to two posts a day on average. Nearly all of the top ten universities have a growing fan base, and all these universities rarely resort to paid content and promoted posts-only approximately $3 \%$ of their posts. Another common aspect is a focus on catchy visual content. That is, the posts are mostly links, videos, or photos, and text-only status posts are avoided. The studied universities also create emotional posts and motivate page visitors to share. Such emotional posts often consist of institution accomplishments, stories regarding well-known individuals, and new ideas, inventions, and studies.

The total number of Facebook fans of the ten selected universities corresponds to the number of students enrolled at each university; universities with more students generally have more fans on Facebook. It is highly interesting that whether a university is located in the USA or UK does not necessarily mean that the most of its fans are also from those countries. In the cases of Caltech and MIT, two technological universities, most of their Facebook fans are from India. The University of Cambridge is located in the United Kingdom, but it has more Facebook fans from India, Pakistan, Egypt, Bangladesh, and the USA than from its home country. The universities generally do not use third-party applications to publish posts on Facebook. Rather, they rely nearly exclusively on the Facebook web page. Regarding engagement rate, MIT has the best overall results, whereas Stanford University has the lowest values. Unlike most consumer brands, the studied universities primarily publish links on Facebook and do not use photos or videos as much as top brands do, although photos achieve the highest engagement. The universities do not follow the latest trends, and they probably do not adequately analyze their Facebook engagement. Thus, they prefer to publish links that drive traffic to their websites instead of publishing more engaging content in the form of photos or videos. The universities also do not promote as many posts as brands do, probably because of stricter budget restrictions. Universities positioned lower in the QS University Rankings are generally not as active on social media, particularly on Facebook, as the top ten institutions. The frequency of their posting is on average one post every few days. Universities lower in the rankings have smaller numbers of social media fans, as expected, and generally limit themselves to posting links, videos, or photos. However, their posts lack the emotional appeal of those published by the top ten universities. They could be recommended to increase their activity on social media to 1 or 2 posts a day and to add more emotional context to their posts. From the perspective of the students, social media services are a highly useful indicator of a university's goals, what a university expects from its students, and even how to find good professors, choose classes, and prepare properly. Students can discuss their questions and concerns with other students who access the university's social media pages and occasionally even with professors or university advisors. 


\section{Discussion}

According to social media specialists, the latest trends in creating university social media content include reporting news, sharing milestones and achievements, managing and publicizing events, gathering reviews from students, and curating user-generated content. It can be stated that the analyzed activity of the universities surveyed largely corresponds to current trends. MIT posts on average one piece of news or other content per workday. CU highlighted its long tradition by listing all major milestones in its history since its founding in 1209. The University of Southern Queensland, Australia, chose to rely on testimonials and collected more than 500 reviews from students. Facebook offers a special section for reviews, where users can rate the service of the page owner, and the owner can respond to reviews. A common feature of the social media communication of educational institutions is to manage a Facebook Group, which facilitates sharing practical information with students and where students can interact. The University of California, Davis, establishes such a group for each new class of students. The group is managed by the university's marketing team and helps students acclimate to their new environment. According to recent data, individuals between 16 and 24 years spend on average nearly two and half hours on social media daily, which represents a substantial amount of time and therefore an excellent opportunity for universities to develop their promotional activities and focus their recruitment campaign on social media.

Despite the limitations of this study, which focuses in detail on a single social network over one year, its findings are consistent with the results of other similar studies [18,28,29].

The authors of [29] also point out the differences in social media behavior and engagement based on the type of a particular university. While public and private universities post more frequently, they attract less engagement than liberal arts colleges, which post less often but draw more attention. This claim has been neither proven nor disproven in our study because the selection of universities as to their type included diverse universities across various subjects. It has been however confirmed that as to the type of media, images were posted most frequently. Posts including images received the most engagement as well. This finding supports the claim that images tend to draw more attention than text-only content. Finally, it should be noted that proportional engagement was spread out over the total number of posts, hence those universities that posted less frequently received more overall engagement per post [29].

Peruta (2017) [29] mentions an interesting discrepancy between the number of fans or followers on social media channels and their individual engagement. Established traditional universities tend to have a high following but the individual fan engagement is paradoxically lower. Our findings also confirmed that both posting too little and posting too much has a negative impact on engagement $[29,43]$.

Peruta (2017) [29] discusses the behavior of universities on social media and the factors that influence the success of their efforts. Our study suggests a negative correlation of an increase in following and an increase in posting frequency. This finding is in keeping with the results of Eyrich et al. [36], who argue that quality is a major factor determining the success on social media. Theoretically, it should follow that the best policy is carefully crafting high-quality posts to present relevant information in an attractive format. In contrast, sacrificing quality to quantity should be poor practice. However, there are also factors beyond the control of the universities. These include, for example, the year when the university was established and when it started to use social media. Both these factors have a positive correlation with the amount of engagement. These findings suggest that the standing of particular universities on social media cannot always be boosted by social media campaigns or rebranding Hilde et al. [36]. However, this is a claim open to discussion and a challenge for the universities.

\section{Conclusions}

Unlike most brand communication channels, social media can provide a large amount of detailed feedback data concerning the behavior of students and other stakeholders and the effectiveness of promotional campaigns. To use social media effectively and utilize their full marketing potential, it is 
necessary to collect the available data and continually analyze and evaluate them to gain insight on which to base an appropriate social media strategy [50-52]. Currently, universities tend to use social media primarily to share the latest news, and the best-performing posts are often those that report on a particular success of the university in a given research area or the success story of an individual student. Another common feature of posts shared by universities are announcements regarding the deaths of world-renowned researchers, in which the universities pay homage and target the emotions of readers.

The question, and perhaps the challenge, remains to focus on subsequent social media brand-building.

By encouraging user-generated content and stimulating word-of-mouth communication, universities can facilitate transparent communication and therefore increase the confidence of users regarding promotional campaigns on social media. Establishing and maintaining open, transparent communication with current and prospective students on social media channels is a complex task. However, these channels are so powerful in influencing users' decisions that it is worthwhile to invest resources into an effective social media communication strategy. Focusing in this direction can be an opportunity and possibly a competitive advantage for universities that do not have such a great history and famous brand.

Author Contributions: P.M. prepared design of study and wrote manuscript, J.H. prepared tables and figure, K.K. wrote the manuscript. All authors reviewed the manuscript. All authors have read and agreed to the published version of the manuscript.

Acknowledgments: This study is supported by internal project SPEV No. 2103 and Excellence 2020, Faculty of Informatics and Management, University of Hradec Kralove, Czech Republic.

Conflicts of Interest: The authors declare that they have no conflict of interest.

\section{References}

1. Hanna, R.; Rohm, A.; Crittenden, V.L. We're all connected: The power of the social media ecosystem. Bus. Horiz. 2011, 54, 265-273. [CrossRef]

2. Constantinides, E.; Stagno, M.C.Z. Potential of the social media as instruments of higher education marketing: A segmentation study. J. Mark. High. Educ. 2011, 21, 7-24. [CrossRef]

3. Perrin, A. Social Media Usage: 2005-2015; Pew Research Center: Washington, DC, USA, 2015.

4. Rutter, R.; Roper, S.; Lettice, F. Social media interaction, the university brand and recruitment performance. J. Bus. Res. 2016, 69, 3096-3104. [CrossRef]

5. Capano, G. Understanding Policy Change as an Epistemological and Theoretical Problem. J. Comp. Policy Anal. Res. Pract. 2009, 11, 7-31. [CrossRef]

6. Diephay, P. Photodune Net/Social Media \& User-Generated Content. Available online: https://www.statista. com/markets/424/topic/540/social-media-user-generated-content/ (accessed on 21 February 2020).

7. Ellison, N.B.; Steinfield, C.; Lampe, C. Connection strategies: Social capital implications of Facebook-enabled communication practices. New Media Soc. 2011, 13, 873-892. [CrossRef]

8. DeAndrea, D.C.; Ellison, N.B.; LaRose, R.; Steinfield, C.; Fiore, A. Serious social media: On the use of social media for improving students' adjustment to college. Internet High. Educ. 2012, 15, 15-23. [CrossRef]

9. Brech, F.M.; Messer, U.; Vander Schee, B.A.; Rauschnabel, P.A.; Ivens, B.S. Engaging fans and the community in social media: Interaction with institutions of higher education on Facebook. J. Mark. High. Educ. 2017, 27, 112-130. [CrossRef]

10. QS|World University and MBA Rankings. QS. Available online: https://www.topuniversities.com/mbarankings/2020 (accessed on 25 October 2019).

11. Bunzel, D.L. Universities sell their brands. J. Prod. Brand Manag. 2007, 16, 152-153. [CrossRef]

12. Khouja, M.; Rodriguez, I.B.; Ben Halima, Y.; Moalla, S. IT Governance in Higher Education Institutions: A Systematic Literature Review. Int. J. Hum. Cap. Inf. Technol. Prof. 2018, 9, 52-67. [CrossRef]

13. Seeber, M.; Cattaneo, M.; Huisman, J.; Paleari, S. Why do higher education institutions internationalize? An investigation of the multilevel determinants of internationalization rationales. High. Educ. 2016, 72, 685-702. [CrossRef]

14. De Sousa Santos, B. Globalizations. Theory Cult. Soc. 2006, 23, 393-399. [CrossRef] 
15. Al-Kurdi, O.; El-Haddadeh, R.; Eldabi, T. Knowledge sharing in higher education institutions: A systematic review. J. Enterp. Inf. Manag. 2018, 31, 226-246. [CrossRef]

16. Strandli Portfelt, I.; Karlstads Universitet, Avdelningen för Pedagogik. The University-A Learning Organization? An Illuminative Review Based on System Theory; Karlstads universitet, Avdelningen för pedagogik: Karlstad, Sweden, 2006.

17. Altbach, P.G. Globalisation and the University: Myths and Realities in an Unequal World. Tert. Educ. Manag. 2004, 10, 3-25. [CrossRef]

18. Rauschnabel, P.A.; Krey, N.; Babin, B.J.; Ivens, B.S. Brand management in higher education: The University Brand Personality Scale. J. Bus. Res. 2016, 69, 3077-3086. [CrossRef]

19. Felix, R.; Rauschnabel, P.A.; Hinsch, C. Elements of strategic social media marketing: A holistic framework. J. Bus. Res. 2017, 70, 118-126. [CrossRef]

20. Reuben, R. The Use of Social Media in Higher Education for Marketing and Communications: A Guide for Professionals in Higher Education; Rachel Reuben Consulting LLC: Kingston, NY, USA, 2008.

21. Laurell, C.; Sandström, C.; Berthold, A.; Larsson, D. Exploring barriers to adoption of Virtual Reality through Social Media Analytics and Machine Learning-An assessment of technology, network, price and trialability. J. Bus. Res. 2019, 100, 469-474. [CrossRef]

22. Moore, J.R.; Caudill, R. The Bot Will See You Now. Psychiatr. Clin. N. Am. 2019, 42, 627-634. [CrossRef]

23. Adeola, O.; Hinson, R.E.; Evans, O. Social Media in Marketing Communications: A Synthesis of Successful Strategies for the Digital Generation. In Digital Transformation in Business and Society; George, B., Paul, J., Eds.; Springer International Publishing: Cham, Switzerland, 2020; pp. 61-81, ISBN 978-3-030-08276-5.

24. Ukpabi, D.C.; Aslam, B.; Karjaluoto, H. Chatbot Adoption in Tourism Services: A Conceptual Exploration. In Robots, Artificial Intelligence, and Service Automation in Travel, Tourism and Hospitality; Ivanov, S., Webster, C., Eds.; Emerald Publishing Limited: Bingley, UK, 2019; pp. 105-121, ISBN 978-1-78756-688-0.

25. Sidhu, R. The 'brand name' research university goes global. High. Educ. 2009, 57, 125-140. [CrossRef]

26. Stephenson, A.L.; Heckert, A.; Yerger, D.B. College choice and the university brand: Exploring the consumer decision framework. High. Educ. 2016, 71, 489-503. [CrossRef]

27. Berggren, C. Labour Market Influence on Recruitment to Higher Education-Gender and Class Perspectives. High. Educ. 2006, 52, 121-148. [CrossRef]

28. Lund, B. Universities engaging social media users: An investigation of quantitative relationships between universities' Facebook followers/interactions and university attributes. J. Mark. High. Educ. 2019, 29, 251-267. [CrossRef]

29. Peruta, A.; Shields, A.B. Social media in higher education: Understanding how colleges and universities use Facebook. J. Mark. High. Educ. 2017, 27, 131-143. [CrossRef]

30. Teh, G.M.; Salleh, A.H.M. Impact of Brand Meaning on Brand Equity Of Higher Educational Institutions in Malaysia. World 2011, 3, 218-228.

31. Whetten, D.A. Albert and Whetten Revisited: Strengthening the Concept of Organizational Identity. J. Manag. Inq. 2006, 15, 219-234. [CrossRef]

32. Novotný, M. Infografika: Mapa sociální sítě. Available online: https://www.markomu.cz/mapa-socialni-site2/ (accessed on 5 October 2018).

33. Mazzarol, T.; Soutar, G.N. Revisiting the global market for higher education. Asia Pac. J. Mark. Logist. 2012, 24, 717-737. [CrossRef]

34. Casidy, R. The role of brand orientation in the higher education sector: A student-perceived paradigm. Asia Pac. J. Mark. Logist. 2013, 25, 803-820. [CrossRef]

35. Owyang, M.T.; Rapach, D.E.; Wall, H.J. States and the business cycle. J. Urban Econ. 2009, 65, 181-194. [CrossRef]

36. Eyrich, N.; Padman, M.L.; Sweetser, K.D. PR practitioners' use of social media tools and communication technology. Public Relat. Rev. 2008, 34, 412-414. [CrossRef]

37. Kietzmann, J.; Hermkens, K.; McCarthy, I.P.; Silvestre, B. Social Media? Get Serious! Understanding the Functional Building Blocks of Social Media; Social Science Research Network: Rochester, NY, USA, 2014.

38. Algharabat, R.; Alalwan, A.A.; Rana, N.P.; Dwivedi, Y.K. Three dimensional product presentation quality antecedents and their consequences for online retailers: The moderating role of virtual product experience. J. Retail. Consum. Serv. 2017, 36, 203-217. [CrossRef] 
39. Taylor, C.R.; Okazaki, S. Social media and international advertising: Theoretical challenges and future directions. Int. Mark. Rev. 2013, 30, 56-71.

40. Internet \& Technology-Pew Research Center. Available online: https://www.pewresearch.org/internet/ (accessed on 28 January 2020).

41. Kuzma, J.M.; Wright, W. Using social networks as a catalyst for change in global higher education marketing and recruiting. IJCEELL 2013, 23, 53. [CrossRef]

42. Kurre, R.; Höne, A.; Clausen, M.; Meel, C.; Maier, B. PilT2 enhances the speed of gonococcal type IV pilus retraction and of twitching motility: PilT2 enhances gonococcal speed. Mol. Microbiol. 2012, 86, 857-865. [CrossRef] [PubMed]

43. Olcay, G.A.; Bulu, M. Is measuring the knowledge creation of universities possible?: A review of university rankings. Technol. Forecast. Soc. Chang. 2017, 123, 153-160. [CrossRef]

44. Klassen, K.M.; Borleis, E.S.; Brennan, L.; Reid, M.; McCaffrey, T.A.; Lim, M.S. What People "Like": Analysis of Social Media Strategies Used by Food Industry Brands, Lifestyle Brands, and Health Promotion Organizations on Facebook and Instagram. J. Med. Internet Res. 2018, 20, e10227. [CrossRef]

45. Tafesse, W.; Wien, A. A framework for categorizing social media posts. Cogent Bus. Manag. 2017, 4, 1284390. [CrossRef]

46. Ramanathan, U.; Subramanian, N.; Parrot, G. Role of social media in retail network operations and marketing to enhance customer satisfaction. Int. J. Oper. Prod. Manag. 2017, 37, 105-123. [CrossRef]

47. Foux, G. Consumer-generated media: Get your customers involved. Brand Strategy. J. Database Mark. Cust. Strategy Manag. 2006, 17, 262-266.

48. Mangold, W.G.; Faulds, D.J. Social media: The new hybrid element of the promotion mix. Bus. Horiz. 2009, 52, 357-365. [CrossRef]

49. Tucker, C.E. Social Networks, Personalized Advertising, and Privacy Controls. J. Mark. Res. 2014, 51, $546-562$. [CrossRef]

50. Maresova, P.; Klimova, B.; Tuček, V. Use of social networks in banking: A study in the Czech Republic. Appl. Econ. 2015, 47, 6155-6169. [CrossRef]

51. Misirlis, N.; Vlachopoulou, M. Social media metrics and analytics in marketing-S3M: A mapping literature review. Int. J. Inf. Manag. 2018, 38, 270-276. [CrossRef]

52. Marešová, P.; Fadeyi, O.; Kuča, K. Are Social Networks Sufficiently Used in Companies? Case Study in the Czech Republic. Sustainability 2020, 12, 1160. [CrossRef] 